\title{
Invitro Susceptibility test of Staphylococcus species Isolated from Sudanese Anterior Nares to different types of Antibiotics
}

\author{
R. M. A. Elsanousi ${ }^{1 *}$ and S. M. El Sanousi ${ }^{2}$ \\ ${ }^{1}$ Department of Microbiology, College of Medicine, University of Bahri, Sudan \\ ${ }^{2}$ Department of Microbiology, Faculty of Veterinary Medicine, \\ University of Khartoum, Sudan \\ *Corresponding author
}

\section{A B S T R A C T}

The aim of this study was to evaluate the susceptibility of Staphylococcus species isolated from the anterior nares of different Sudanese population to various antibiotics. The bacteria were isolated and identified using cultural and biochemichal procedures. Twenty five Staphylococcus isolates were applied in this study including eleven species and two sub species.They were: Staph.epidermidis,

Keywords

Staphylococcus species, Antibiotics, Sensitivity test

\section{Article Info}

Accepted:

05 April 2020

Available Online:

10 May 2020
Staph.aureus, Staph.capitis, Staph.hyicus (coagulase-positive), Staph.hyicus (coagulase-negative), Staph.caseolyticus, Staph.simians, Staph.lugdunensis, Staph.delphini, Staph.schleiferi, Staph.hominis, Staph.capitis sub spp ureolyticus and Staph.Cohni sub spp ureolyticus. One isolate for Staph.hyicus coagulase-positive, Staph.cohni sub spp ureolyticus and Staph.schleiferi, three isolates for Staph.aureus, Staph.epidermidis and two isolates for the rest.The identified isolates were subjected to sensitivity test using disc diffusion method. Seventeen types of antibiotics were used: vancomycin, cefuroxime, cefotaxime, methicillin, penicillin, ampicillin, cloxacillin, ciprofloxacin, gentamicin, erythromycin, tetracycline, streptomycin, colistin, nalidixic acid, chloramphenicol, cotrimoxazol and nitrofurantoin. All of the isolates were sensitive to vancomycin, cefuroxime, cefotaxime, ciprofloxacin, gentamicin, tetracycline, streptomycin, colistin, chloramphenicol and nitrofurantoin. Antibiotics resistance -patternes were reported as: $52 \%$ for methicillin, $44 \%$ for penicillin, $36 \%$ for co-trimoxazol, $20 \%$ for ampicillin, $20 \%$ for nalidicxic acid, $12 \%$ for cloxacillin and $4 \%$ for erythromycin. Staphylococcus aureus isolates were resistant to methicillin, penicillin and nalidixic acid. Staph.epidermidis isolates were resistant to penicillin and co-trimoxazol. Staph.hyicus coagulase-positive showed multi drug resistantce. Methicillin resistance was domenant in this study.

\section{Introduction}

Antimicrobial resistance can increase the morbidity, mortality and treatment cost of Staphylococcal infections (Hartman etal., 1984). Multi drug resistance in pathogenic and opportunistic bacteria was increasingly documented. These bacteria pose life threatening risks to the hospitalized patients and their caregivers (Jones et al., 2004). Staphylococci are one of the most numerous resistances to many prescribed antibiotics (Mun et al., 2013). Both strains of Staphylococcus aureus and Staphylococcus epidermidis have accumulated multiple resistance determinants (Archer et al., 1994). 
One mode of penicillin-resistant action of bacteria is by producing $\beta$-lactamase to destroy penicillins (Tenover, 2006). Staphylococcus epidermidis and other coagulase-negative Staphylococci (CoNS) are leading causes of surgical site and centralline-associated blood stream infections (Sievert $e T$ al., 2013and Otto, 2009). Little is understood about the mechanisms of pathogenesis and optimal treatment of Staphylococcus epidermidis.

Many of the clinical decisions made when treating this species are based on assumptions from studies in Staphylococcus aureus. Staphylococcus aureus is considered to be the most virulent and is the leading cause of healthcare - associated infections (Klein et al., 2007). Coagulase-negative Staphylococci (CoNS) are frequently associated with catheter and prosthetic device infections. Antimicrobial therapy is essential for most Staphylococcal infections, and in vitro susceptibility testing plays a pivotal role in the selection of antimicrobial agents (Aldridge, 1995). For most Staphylococcal isolates, susceptibility to penicillinase resistant penicillins (eg, oxacillin) is the most important result. Methicillin resistant Staphylococcus aureus (MRSA) becomes a prime nosocomial pathogen for patients in hospitals and nursing homes during the past ten years (Boyce, 2007, Chamber et al., 2009, Hardy et al., 2006 and Kallen et al., 2010).

The use of antibiotics in humans and in animals (therapeutic, growth promotion and prophylactic) possibly led to the selective increase of resistance in bacterial populations (Suleiman et al., 2013). The methicillin resistance of Staphylococci is mediated by the mec A gene, which is carried by a mobile genetic element known as the Staphylococcal cassette chromosome mec (SCCmec) (Vanegas-López et al., 2012). The penicillin binding protein $2 \mathrm{a}$ (PBP2a) has a reduced affinity for beta-lactam antibiotics, resulting in resistance to most beta-lactam antimicrobial agents (Mirzaei et al., 2012 and Yamada et al., 2013). The continued emergence of antimicrobial drug resistance is a serious problem for the antibiotic treatment of patients with Staphylococcal infections in the clinic. Studies by Kuehnert et al., (2006) reported that $60-85 \%$ of Staphylococcus strains isolated from clinical samples were resistant to methicillin. The major problem lies in the fact that infections caused by methicillin-resistant Staphylococcus strains (MRS) were difficult to treat. In some cases, the isolates were only susceptible to glycopeptides and new drugs, such as linezolid, tigecycline, daptomycin and quinupristin/dalfopristin (Critchley et al., 2003 and Otto, 2009). Staphylococcus species that was prevalent in animals associated with frequent resistance to methicillin was Staphylococcus schleiferi (Griffeth et al., 2008 and Kawakami et al., 2010). Coagulasenegative MRS species such as Staphylococcus epidermidis, Staphylococcus haemolyticus, Staphylococcus lentus, Staphylococcus sciuri, and Staphylococcus simulans were isolated from animals.(Van Duijkeren et al., 2004, Feßler et al., 2010 and Chah etal., 2014).

\section{Materials and Methods}

The bacterial isolation and identification were performed using traditional cultural procedures according to Barrow and Feltham, (2003).Media were obtained and prepared according to the methods described by Oxoid (Oxoid, Laboratories, London).Reagents were obtained from the British Drug House Chemicals (BDH ltd Poole, England). All biochemical confirmatory tests were performed according to Sneath et al., (1986), Barrow and Feltham, (2003) and El Sanousi et al., (2015).

Randomly 25 isolates were selected of 164 Staphylococcus positive results that were 
isolated from a total of 200 nasal swab specimens taken from sudanese community including: Hospital staff, subject in contact with animals, subject worked in clean environments (not in contact with patients or animal) and children group with virtually 50 samples for each group. The isolates included eleven species and two sub species. These were: Staph.epidermidis, Staph.aureus, Staph.capitis, Staph.hyicus (coagulasepositive), Staph.hyicus (coagulase-negative), Staph.caseolyticus, Staph.Simians, Staph. lugdunensis, Staph.delphini, Staph.schleiferi, Staph.hominis, Staph.capitis sub spp ureolyticus and Staph.cohni sub spp ureolyticus. One isolate for Staph.hyicus coagulase-positive, Staph.cohni sub spp ureolyticus and Staph.schleiferi, three isolates for Staph.aureus and Staph.epidermidis and two isolates for the rest.

The identified isolates were subjected to susceptibility test using disc diffusion method according to Cheesbrough, (2000).A plate of nutrient agar was dried in the incubator for 30 minutes then a diluted suspension of the organism was poured onto the surface of the medium. Using sterile forceps, the antibiotic discs were gently applied on the plate and incubated at $37^{\circ} \mathrm{C}$ for 24 hours. The zones of inhibition were measured in millimetres using a ruler and defined according to the chart within the ranges.

Results interpretation was done in accordance with the zone size interpretative chart of the manufacturer. Susceptibility of Staphylococcus species were done to seventeen types of antibiotics: Ampicillin $(10 \mu \mathrm{g})$, co-trimoxazol $(25 . \mu \mathrm{g})$, gentamicin $(10 \mu \mathrm{g})$, streptomycin $(10 \mu \mathrm{g})$, tetracycline $(10 \mu \mathrm{g})$, nalidixic acid $(30 \mu \mathrm{g})$, nitrofurantoin $(200 \mu \mathrm{g})$, colistin(25 $\mu \mathrm{g})$, cloxacillin $(5 \mu \mathrm{g})$, chloramphenicol $(10 \mu \mathrm{g})$, erythromycin $(5 \mu \mathrm{g})$, penicillin(1 I.U), all of these were obtained from (Plasmatec Lab. Products Ltd, U.K).
Ciprofloxacin $(5 \mu \mathrm{g})$ (CIP/A LTD. Mumbae Central, India), cefuroxime $(30 \mu \mathrm{g})$, Cefotaxime $(30 \mu \mathrm{g})$, methicillin $(10 \mu \mathrm{g})$ (MAST Diagnostics, Mast Group Ltd. Merseyside, U.K.) and vancomycin (30 $\mu \mathrm{g})$ (Oxoid).

\section{Results and Discussion}

All of the isolate were sensitive to vancomycin, cefuroxime, cephotaxime, ciprofloxacin, gentamicin, tetracycline, streptomycin, colistin, chloramphenicol and nitrofurantoin (Table-1). Staphylococcus epidremidis showed large zones of inhibition to cephalosporins, ciprofloxacin and nitrofurantoin (Table-3).Antibiotics resistance patternes were reported as: $52 \%$ for methicillin, $44 \%$ for penicillin, $36 \%$ for cotrimoxazol, $20 \%$ for ampicillin, $20 \%$ for nalidixic acid, $12 \%$ for cloxacillin and $4 \%$ for erythromycin (Table-2). Staphylococcus aureus were resistant to methicillin, penicillin and nalidixic acid. Staphylococcus epidermidis isolates resisted penicillin and cotrimoxazol, Staphylococcus hominis resisted methicillin and penicillin while Staphylococcus caseolyticus resisted methicillin and nalidixic acid. Staphylococcus hyicus coagulase-positive gave multi drug resistantce results. Methicillin resistance was reported in nine species among these isolates (Table -2).

The identified isolates were subjected to the susceptibility test using disc diffusion method to seventeen types of antibiotics. Cefuroxime, cefotaxime, ciprofloxacin, gentamicin, tetracycline, streptomycin, vancomycin, nitrofurantoin, colistin and chloramphenicol gave different degrees of inhibition to all isolates.

Most of the isolates were resistant to penicillin and methicillin. Staphylococcus aureus isolates showed resistant pattens to 
methicillin, penicillin, and nalidixic acid. Staphylococcus epidermidis isolates were resistant to penicillin and co-trimoxazol.

Methicillin resistance was reported in nine species which were comparable with a result obtained by Phophi, et al., (2019) on antimicrobial resistance patterns of coagulase - negative Staphylococcus species included: Staphylococcus epidermidis, Staphylococcus hominis and Staphylococcus hyicus. This study revealed that the majority of coagulase negative Staphylococci (CoNS) gave high rate of sensitivity to cefoxitin and vancomycin.
Most of them were $\beta$-lactam resistant in particular to penicillins and ampicillin. Our study agreed with a previous study performed by Lee et al., (2006) who evaluated the suitable antibiotics used for the treatment of catheter- related infections caused by Staphylococci. The study conducted proved that $5 \mathrm{mg} / \mathrm{ml}$ of vancomycin and ciprofloxacin can eradicate Staphylococcus aures and Staphylococcus epidermidis within five days, while complete eradication was not achieved with erythromycin and other drugs under investigation.

Table.1 Antibiotics susceptibility patterns of Staphylococcus species.

\begin{tabular}{|c|c|c|c|c|}
\hline Antibiotics & $\begin{array}{c}\text { Sensitive zone: } \\
1.2 \text { - } \infty \mathrm{mm} \\
\text { No. of isolates }\end{array}$ & $\begin{array}{c}\text { Intermediate } \\
\text { zone: } 0.4-1.1 \mathrm{~mm} \\
\text { No. of isolates }\end{array}$ & $\begin{array}{c}\text { Resistance zone: } \\
\leq \mathbf{0 . 3} \\
\text { No. of isolates }\end{array}$ & $\begin{array}{c}\text { Percentages of } \\
\text { sensitivity } \\
\%\end{array}$ \\
\hline Cefotaxime $(30 \mu \mathrm{g})$ & 18 & 7 & - & $100 \%$ \\
\hline Cefuroxime $(30 \mu \mathrm{g})$ & 19 & 6 & - & $100 \%$ \\
\hline Cloxacillin ( $5 \mu \mathrm{g})$ & 15 & 7 & 3 & $88 \%$ \\
\hline Ampicillin $(10 \mu \mathrm{g})$ & 11 & 9 & 5 & $80 \%$ \\
\hline Penicillin (1i.u.) & 7 & 7 & 11 & $56 \%$ \\
\hline Methicillin $(10 \mu \mathrm{g})$ & 6 & 6 & 13 & $48 \%$ \\
\hline Nitrofurantoin $(200 \mu \mathrm{g})$ & 21 & 4 & - & $100 \%$ \\
\hline Ciprofloxacin $(5 \mu \mathrm{g})$ & 20 & 5 & - & $100 \%$ \\
\hline Gentamicin $(10 \mu \mathrm{g})$ & 19 & 6 & - & $100 \%$ \\
\hline Streptomycin $(10 \mu \mathrm{g})$ & 13 & 12 & - & $100 \%$ \\
\hline Tetracycline $(10 \mu \mathrm{g})$ & 12 & 13 & - & $100 \%$ \\
\hline Vancomycin $(30 \mu \mathrm{g})$ & 11 & 14 & - & $100 \%$ \\
\hline $\begin{array}{l}\text { Chloramphenicol(10 } \\
\mu \mathrm{g})\end{array}$ & 9 & 16 & - & $100 \%$ \\
\hline Colistin $(25 \mu \mathrm{g})$ & 8 & 17 & - & $100 \%$ \\
\hline Erythromycin $(5 \boldsymbol{\mu g})$ & 14 & 10 & 1 & $96 \%$ \\
\hline Nalidixic acid(30 $\mu \mathrm{g})$ & 8 & 12 & 5 & $80 \%$ \\
\hline Co-trimoxazol $(25 \mu \mathrm{g})$ & 8 & 8 & 9 & $64 \%$ \\
\hline
\end{tabular}


Table.2 Antibiotics resistant species (zone of inhibition: $\leq 0.3 \mathrm{~mm}$ )

\begin{tabular}{|c|c|c|c|}
\hline Staphylococcus resistant species & Antibiotics & $\begin{array}{l}\text { No. of the } \\
\text { isolates }\end{array}$ & $\begin{array}{c}\text { Percentages of } \\
\text { Resistant }(\%)\end{array}$ \\
\hline Staph.hyicus coagulase -positive & $\begin{array}{l}\text { Erythromycin } \\
\qquad(5 \mu \mathrm{g})\end{array}$ & 1 & 4 \\
\hline $\begin{array}{l}\text { Staph.hyicus coagulase- positive } \\
\text { Staph.hyicus coagulase- negative }\end{array}$ & Cloxacillin $(5 \mu \mathrm{g})$ & $\begin{array}{l}1 \\
2\end{array}$ & $12 \%$ \\
\hline $\begin{array}{l}\text { Staph.hyicus coagulase -negative } \\
\text { Staph.hyicus coagulase- positive } \\
\text { Staph.delphini } \\
\text { Staph.cohni sub spp ureolyticus }\end{array}$ & Ampicillin $(10 \mu \mathrm{g})$ & $\begin{array}{l}1 \\
1 \\
2 \\
1\end{array}$ & $20 \%$ \\
\hline $\begin{array}{c}\text { Staph.cohni sub spp ureolyticus } \\
\text { Staph.hyicus coagulase -positive } \\
\text { Staph.caseolyticus } \\
\text { Staph.aureus }\end{array}$ & $\begin{array}{l}\text { Nalidixic acid } \\
\qquad(30 \mu \mathrm{g})\end{array}$ & $\begin{array}{l}1 \\
1 \\
2 \\
1\end{array}$ & $20 \%$ \\
\hline $\begin{array}{c}\text { Staph.lugdunensis } \\
\text { Staph.delphini } \\
\text { Staph.epidermidis } \\
\text { Staph.hyicus coagulase -positive } \\
\text { Staph.simians }\end{array}$ & Co-trimoxazol $(25 \mu \mathrm{g})$ & $\begin{array}{l}2 \\
2 \\
2 \\
1 \\
2\end{array}$ & $36 \%$ \\
\hline $\begin{array}{c}\text { Staph.hominis } \\
\text { Staph.aureus } \\
\text { Staph.hyicus coagulase -negative } \\
\text { Staph.hyicus coagulase- positive } \\
\text { Staph.delphini } \\
\text { Staph.epidermidis } \\
\text { Staph.cohni sub spp ureolyticus }\end{array}$ & Penicillin (1i.u.) & $\begin{array}{l}1 \\
2 \\
2 \\
1 \\
2 \\
2 \\
1\end{array}$ & $44 \%$ \\
\hline $\begin{array}{c}\text { Staph.hyicus coagulase -negative } \\
\text { Staph.hyicus coagulase -positive } \\
\text { staph.delphini } \\
\text { staph.capitis } \\
\text { Staph.capitis sub spp ureolyticus } \\
\text { Staph.cohni sub } \\
\text { spp ureolyticus } \\
\text { Staph.hominis } \\
\text { Staph.caseolyticus } \\
\text { Staph.aureus }\end{array}$ & Methicillin $(10 \mu \mathrm{g})$ & $\begin{array}{l}2 \\
1 \\
2 \\
1 \\
1 \\
1 \\
1 \\
2 \\
2\end{array}$ & $52 \%$ \\
\hline
\end{tabular}


Table.3 Antibiotics highly sensitive species (zone of inhibition: $\geq 1.6 \mathrm{~mm}$ )

\begin{tabular}{|c|c|c|c|}
\hline Staphylococcus spps & Antibiotics & No of isolates & Percentages \% \\
\hline $\begin{array}{c}\text { Staph.epidermidis } \\
\text { Staph.cohni sub spp ureolyticus } \\
\text { Staph.hominis } \\
\text { Staph.caseolyticus } \\
\text { Staph.simians }\end{array}$ & Cefotaxime $(30 \mu \mathrm{g})$ & $\begin{array}{l}2 \\
1 \\
1 \\
2 \\
2\end{array}$ & $32 \%$ \\
\hline $\begin{array}{c}\text { Staph.epidermidis } \\
\text { Staph.capitis } \\
\text { Staph.cohni sub spp ureolyticus } \\
\text { Staph.caseolyticus } \\
\text { Staph.simians }\end{array}$ & Cefuroxime $(30 \mu \mathrm{g})$ & $\begin{array}{l}2 \\
1 \\
1 \\
1 \\
2\end{array}$ & $28 \%$ \\
\hline $\begin{array}{c}\text { Staph.hyicus coagulase - negative } \\
\text { Staph.epidermidis } \\
\text { Staph.hominis } \\
\text { Staph.caseolyticus } \\
\text { Staph.simians }\end{array}$ & Ciprofloxacin $(5 \mu \mathrm{g})$ & $\begin{array}{l}1 \\
1 \\
1 \\
1 \\
1\end{array}$ & $20 \%$ \\
\hline $\begin{array}{c}\text { Staph.hominis } \\
\text { Staph.lugdunensis } \\
\text { Staph.delphini } \\
\text { Staph.epidermidis }\end{array}$ & $\begin{array}{l}\text { Nitrofurantoin } \\
\quad(200 \mu \mathrm{g})\end{array}$ & $\begin{array}{l}1 \\
1 \\
1 \\
1\end{array}$ & $16 \%$ \\
\hline $\begin{array}{l}\text { Staph.hominis } \\
\text { Staph.simians } \\
\text { Staph.delphini }\end{array}$ & Gentamicin $(10 \mu \mathrm{g})$ & $\begin{array}{l}1 \\
1 \\
1\end{array}$ & $12 \%$ \\
\hline $\begin{array}{c}\text { Staph.hyicus } \\
\text { coagulase - } \\
\text { positive } \\
\text { Staph.simians }\end{array}$ & $\begin{array}{l}\text { Streptomycin } \\
\qquad(10 \mu \mathrm{g})\end{array}$ & $\begin{array}{l}1 \\
1\end{array}$ & $8 \%$ \\
\hline $\begin{array}{c}\text { Staph.simians } \\
\text { Staph.hyicus coagulase- positive }\end{array}$ & $\begin{array}{l}\text { Chloramphenicol } \\
\qquad(10 \mu \mathrm{g})\end{array}$ & $\begin{array}{l}1 \\
1\end{array}$ & $8 \%$ \\
\hline $\begin{array}{l}\text { Staph.hominis } \\
\text { Staph.simians }\end{array}$ & Erythromycin $(5 \mu \mathrm{g})$ & $\begin{array}{l}1 \\
1\end{array}$ & $8 \%$ \\
\hline Staph.simians & Cloxacillin $(5 \mu \mathrm{g})$ & 2 & $8 \%$ \\
\hline Staph .simians & Ampicillin $(10 \mu \mathrm{g})$ & 2 & $8 \%$ \\
\hline Staph.simians & Tetracycline $(10 \mu \mathrm{g})$ & 1 & $4 \%$ \\
\hline
\end{tabular}

Methicillin resistant Staphylococcus aureus was shown in $(8 \%)$ of the isolates under the study. This result was comparable with a result carried out by Tigabu et al., (2018) whom isolated and identified methicillin resistant Staph aureus (MRS) in 14 (9.7\%) of $143(23 \%)$ isolates of Staphylococcus aureus from a total of 622 nasal swab specimens collected from school children in Ethiopia. The study also reported that, gentamicin, clindamycin, and ciprofloxacin were the most effective antibiotics whereas penicillin and tetracycline were not effective.

The study concluded that different Staphylococcus species under the in vitro antibiotic susceptibility test showed variable degrees of sensitivity to cephalosporins, vancomycin, ciprofloxacin, gentamicin, tetracycline, streptomycin, chloramphenicol, nitrofurantoin and colistin, while they were resistant to methicillin, penicillins, ampicillin, cloxacillin, nalidixic acid, co-trimoxazol and erythromycin 


\section{References}

Aldridge, K.E.(1995). Cefotaxime in the treatment of Staphylococcal infections. Comparison of in vitro and in vivo studies.Diagn Microbiol Infect Dis.; 22:195-201.

Archer, G.L., Climo, M.W(1994). Antimicrobial susceptibility of coagulase-negative Staphylococci. Antimicrob Agents Chemother.; 38:2231-7.

Barrow, G. L.and Felthman, R. K. A (2003).Cowan and Steels manual for the identification of Medical Bacteria. 3rded.Cambridge University Press, U. K.

Boyce, J. M (2007). "Environmental contamination makes an important contribution to hospital infection, " Journal of HospitalInfection, 65 (2) 50-54

Chah, K.F., Gomez-Sanz, E., Nwanta, J.A., Asadu, B., Agbo, I.C., Lozano, C., et al., (2014).Methicillin-resistant coagulasenegative Staphylococci from healthy dogs inNsukka, Nigeria. Braz J Microbiol.; 45:215-20.

Chambers, H. F.and Deleo, F. R(2009)."Waves of resistance: Staphylococcus aureus in the antibiotic era," Nature ReviewsMicrobiology, 7, (9) 629-64

Cheesbrough, M (2000). District Laboratory Practice in Tropical Countries, Part 2 Second Edition, Cambridge university press.

Critchley, I.A., Blosser-Middleton, R.S., Jones, M.E(2003). Baseline study to determine in vitro activities of daptomycin against Gram-positive pathogens isolated in the United States in 2000-2001. Antimicrob Agents Chemother 47: 1689-1693.

El Sanousi, S.M., Said K.B., Elbager, S., Awad, A., Rodwan, K., Eltom, K.H (2015). Aflow chart for the identification of Staphylococcus species $U$. of $K$. J. Vet. Med. Anim. Prod.6, (2) :93-97

Feßler, A.T., Billerbeck, C., Kadlec, K., Schwarz, S (2010). Identification and characterization of methicillin-resistant coagulase-negative Staphylococci from bovine mastitis. J Antimicrob Chemother, 65:1576-82.

Griffeth, G.C., Morris, D.O., Abraham, J.L., Shofer, F.S., Rankin, S.C (2008).
Screening for skin carriage of methicillinresistant coagulase-positive Staphylococci and Staphylococcus schleiferi in dogs with healthy and inflamed skin.Vet. Dermatol, 19: 142-9.

Hardy, K. J., Oppenheim, B. A., Gossain, S., Gao, F., and Hawkey, P. M (2006).“A study of the relationship between environmental contamination with methicillin-resistant Staphylococcus aureus (MRSA) and patients' acquisition of MRSA, "Infection Control \& Hospital Epidemiology, 27(2): 127-132,

Hartman, B.J., Tomasz, A (1984).Low-affinity of penicillin-binding protein associated with beta-lactam resistance in Staphylococcus aureus. J Bacteriol 158(2):513-516.

Jones, M.E., Draghi, D.C., Thornsberry, C., Karlowsky, J.A., Sahm, D.F., Wenzel, R.P (2004).Emerging resistance among bacterial pathogens in the intensive care unit-a European and North American Surveillance study (2000-002).Ann Clin Microbiol Antimicrob.;3:14.

Kallen, A. J., Mu, Y., Bulens, S., et al., (2010). "Health care-associated invasive MRSA infections, 2005-2008, " JAMA, 304 (6): 641-648.

Kawakami, T., Shibata, S., Murayama, N., Nagata, M., Nishifuji, K., Iwasaki, T., et al., (2010).Antimicrobial susceptibility and methicillin resistance in Staphylococcus pseudintermedius and Staphylococcus schleiferi subsp. coagulans isolated from dogs with pyoderma in Japan. J Vet Med Sci.; 72:1615-9.

Klein, E., Smith, D.L., Laxminarayan, R( 2007).Hospitalizations and deaths caused by methicillin-resistant Staphylococcus aureus, United States, 1999-2005. Emerg Infect Dis.; 13:1840-6.

Kuehnert, M.J., Kruszon-Moran, D., Hill, H.A., McQuillan, G., McAllister, K., Fosheim, G., McDougal, L.K., Chaitram, J., Jensen, B., Fridkin, S.K., Killgore, G., Tenover, F.C(2006).Prevalence of Staphylococcus aureus nasal colonization in the United States, 2001-2002. J Infect Dis 193: 172179.

Lee, J.Y., Ko, S.K., Peck, K.R., Oh, W.S., Song, 
J.H(2006).In vitro evaluation of the antibiotic lock technique (ALT) for the treatment of catheter-related infections caused by Staphylococci.Journal of Antimicrobial chemo therapy 57(6):1110 1115.

Mirzaei, H., Farhoudi, H., Tavassoli, H., Farajli, M., Monadi, A (2012).Presence and antimicrobial susceptibility of methicillin resistant Staphylococcus aureus in raw and pasteurized milk and ice cream in Tabriz by cultureand PCR techniques. Afr. J. Microbiol. Res., 6, 6224-6229.

Mun, S.H., Joung, D.K., Kim, Y.S., Kang, O.H., Kim, S.B., Seo, Y.S., et al., (2013). Synergistic antibacterial effect of curcumin against methicillin-resistant Staphylococcus aureus. Phyto medicine.; 20:714-8.

Otto, M (2009). Staphylococcus epidermidis-the 'accidental' pathogen. Nat. Rev. Microbiol 7, 555-567.

Phophi, L., Petzer, I.M. Qekwana, D.N (2019). Antimicrobial resistance patterns and biofilm formation of coagulase-negative Staphylococcus species isolated from sub clinical mastitis, cow milk samples submitted to the Onderstepoort Milk Laboratory. BMC Veterinary Research, $15: 42$

Sievert, D.M et al., (2013). Antimicrobialresistant pathogens associated with healthcare-associated infections: summary of data reported to the National Healthcare Safety Network at the Centers for Disease Control and Prevention, 2009-2010. Infect. Control Hosp. Epidemiol 34, 1-14.

Sneath, P. H. A., Mair, N. S., Sharpe, M. E. and Holt, J. G (1986). Bergy's Manual of Systematic Bacteriology.Vol., 8th ed.
Williams and Wilkins, Baltimore and London, UK.

Suleiman, A., Zaria, L.T., Grema, H.A., Ahmadu, $\mathrm{P}(2013)$.Antimicrobial resistant coagulase positive Staphylococcus aureus from chickens in Maiduguri, Nigeria. Sokoto J. Vet. Sci., 11, 51-53.

Tenover, F.C.( 2006).Mechanisms of antimicrobial resistance in bacteria. Am J Med;119: S3-10.

Tigabu, A., Tiruneh, M., Mekonnen, F(2018).Nasal Carriage Rate, Antimicrobial Susceptibility Pattern, and Associated Factors of Staphylococcus aureus with Special emphasis on MRSA among Urban and Rural Elementary SchoolChildren in Gondar, Northwest Ethiopia: A Comparative Cross-Sectional Study. Advances in Preventive, Medicine., ID 9364757 https://doi.org/10.1155/2018/9364757.

Van Duijkeren, E., Box, A.T., Heck, M.E., Wannet, W.J., Fluit, A.C (2004). Methicillin-resistant Staphylococci isolated from animals.Vet.Microbiol.; 103: 91-7.

Vanegas-López, M.C., Moreno, E.J., Rueda, R.V., Chirivi, S.J., Garzón, A., Arévalo, A.S., Martínez, F.M., Gardeazábal, P.A., Baquero, C. (2012).Methicillin-resistant Staphylococcus aureus (MRSA) isolated from Colombian foods. Can. Cent. Acad. Art Sci., 2, 61-67.

Yamada, K., Wanchun, J., Ohkura, T., Murai, A., Hayakawa, R., Kinoshita, K., Mizutani, M., Okamoto, A., Namikawa, T., Ohta, M (2013). Detection of methicillin-resistant Staphylococcus aureus using a specific anti-PBP2a chicken IgY antibody. Jpn. J. Infect. Dis., 66, 103-108.

\section{How to cite this article:}

Elsanousi. R. M. A. and El Sanousi. S. M. 2020. Invitro Susceptibility Test of Staphylococcus species Isolated from Sudanese Anterior Nares to different types of Antibiotics. Int.J.Curr.Microbiol.App.Sci. 9(05): 1006-1013. doi: https://doi.org/10.20546/ijcmas.2020.905.110 